Kumawula, Vol. 3, No.3, Desember 2020, Hal 477 - 483 DOI: https://doi.org/10.24198/kumawula.v3i3.29604

ISSN 2620-844X (online)

Tersedia online di http://jurnal.unpad.ac.id/kumawula/index

\title{
PENYULUHAN LITERASI DIGITAL BAGI GURU-GURU SMP DI KOTA SUKABUMI
}

\author{
Susi Yuliawati ${ }^{*}$, Dadang Suganda ${ }^{2}$, Nani Darmayanti ${ }^{3}$ \\ ${ }^{1}$ Fakultas Ilmu Budaya, Universitas Padjadjaran \\ ${ }^{2}$ Fakultas Ilmu Budaya, Universitas Padjadjaran \\ ${ }^{3}$ Fakultas Ilmu Budaya, Universitas Padjadjaran \\ *Korespondensi : susi.yuliawati@unpad.ac.id
}

\begin{abstract}
ABSTRAK
Bagi masyarakat pengguna internet, memiliki pengetahuan dan kecakapan menggunakan teknologi digital untuk mengakses dan mengelola informasi; membangun pengetahuan baru; serta berkomunikasi dengan orang lain agar terhubung dan berpartisipasi secara efektif di masyarakat adalah suatu keharusan. Oleh karena itu, kegiatan PPM ini menerapkam metode penyuluhan mengenai literasi digital kepada guru-guru SMP di Kota Sukabumi. Peserta kegiatan penyuluhan ini adalah dua puluh orang guru SMP dari sebelas Sekolah Menengah Pertama yang berbeda di Kota Sukabumi, yaitu SMPN 1, SMPN 2, SMPN 4, SMPN 5, SMPN 6, SMPN 7, SMPN 13, SMPN 14, SMPN 15, SMPN 16, dan SMP Mardi Waluya 2 yang berstatus sebagai guru Bimbingan Konseling (BK). Literasi digital adalah istilah yang mengacu pada pengetahuan dan kecakapan menggunakan media digital, perangkat komunikasi, dan jaringan untuk menemukan, membuat, dan mengevaluasi informasi, serta menggunakannya secara bijak, cerdas, cermat, tepat, sehat, dan taat hukum dalam rangka menjalin interaksi dalam kehidupan sehari-hari. Didasari oleh konsep tersebut, kegiatan ini ditujukan untuk membantu meningkatkan pengetahuan dan kesadaran para pendidik di tingkat Sekolah Menengah Pertama tentang dampak penggunaan teknologi digital sehingga mereka dapat memanfaatkan teknologi digital secara bijak dan penuh bertanggung jawab. Selanjutnya, pengetahuan dan kesadaran tersebut dapat mereka tularkan pada para anak didik mereka. Berdasarkan hasil kegiatan penyuluhan ini, pengetahuan guru mengenai cara berkomunikasi yang bijak di media sosial, perbedaan berita akurat dan hoax, dan bahaya ujaran kebencian menjadi meningkat dengan baik yang akhirnya diharapkan dapa mencitakan harmonisasi sosial.
\end{abstract}

\begin{abstract}
It is a must for internet users to have the knowledge and skills to use digital technology, access and manage information, build new knowledge, and communicate with others to connect and participate effectively in society. Therefore, this community service (Pengabdian Kepada Masyarakat) is a digital literacy extension to junior high school teachers in Sukabumi City. The participants of the community service were twenty teachers from eleven junior high schools in Sukabumi City, namely SMPN 1, SMPN 2, SMPN 4, SMPN 5, SMPN 6, SMPN 7, SMPN 13, SMPN 14, SMPN 15, SMPN 16, and SMP Mardi Waluya 2, who are Guidance and Counseling teachers. Digital literacy is a term that refers to knowledge and skills of using digital media, communication tools, and networks to find, create and evaluate information, as well as to use it wisely, smartly, responsibly, and by the law in order to establish interactions in daily life. Based on this concept, this community service aims to help increase the knowledge and awareness of teachers at the junior high school level about the impact of the use of digital technology, and hence they can utilize digital technology wisely and responsibly. Furthermore, they are expected to pass on this knowledge and awareness to their students. After this community service was hold, the obvious change is the increase in the participants' knowledge about how to communicate wisely on social media, to separate reliable news from hoaxes, and to build awareness of the dangers of hate speech for social harmony.
\end{abstract}

Keywords: Digital literacy; Internet;Primary education; Social harmony Teachers. 


\section{PENDAHULUAN}

Indonesia, negara kelima yang memiliki jumlah penduduk terbanyak di dunia, telah menjadikannya sebagai salah satu negara yang memiliki jumlah pengguna internet terbesar di dunia. Menurut Rizkinaswara (2019), pengguna internet di Indonesia berjumlah 150 juta orang dengan penetrasi $56 \%$ yang tersebar di seluruh wilayah. Kemudian, pada bulan Januari 2020, pengguna internet di Indonesia telah mencapai 175.4 juta orang (Kemp, 2020). Angka ini menunjukkan bahwa perkembangan penggunaan teknologi digital di Indonesia sangat pesat.

Perkembangan dunia digital tidak hanya menimbulkan peluang, tetapi juga tantangan dan kekhawatiran. Seperti yang kita ketahui, dunia digital telah membuat perkembangan teknologi melesat, membuka peluang-peluang bisnis berbasis internet, memungkinkan manusia terhubung secara global, dan mempermudah manusia mengakses serta sekaligus menyebarkan informasi secara luas. Munculnya beragam media sosial sebagai sarana komunikasi di era digital memungkinkan penggunanya untuk bertukar informasi atau memberikan respon secara online dalam waktu singkat (Susanti, Gunawan, \& Sukaesih, 2019). Salah satu kekhawatiran dari kemajuan pesat teknologi digital ini berkenaan dengan pemanfaatannya di kalangan generasi muda. Data statistik menunjukkan bahwa generasi muda adalah generasi yang paling banyak mengakses internet, yaitu sekitar 70 juta orang (Nasruallah, dkk., 2017). Mereka telah menghabiskan banyak waktu untuk mengakses internet melalui berbagai media, misalnya telepon seluler, komputer, dan laptop.

Keresahan yang ditimbulkan oleh penetrasi teknologi digital, khususnya internet, terhadap generasi muda dipicu oleh sejumlah fenomena sosial yang terjadi di masyarakat Indonesia. Sebagai contohnya, salah satu data menyebutkan bahwa anak Indonesia yang mengakses konten berbau pornografi per harinya mencapai 25 ribu orang (Nursalikah, 2016). Kemudian, berita terbaru melaporkan bahwa sekelompok anak melakukan penipuan online bernilai ratusan juta rupiah dan hasilnya itu mereka gunakan untuk berfoya-foya (Luxiana, 2020). Selain itu, terdapat juga beberapa kasus yang diberitakan oleh media massa berkenaan dengan tindakan kekerasan verbal (cyber bulliying), ujaran kebencian hate speech, dan penyebaran berita bohong (hoax), yang dilakukan oleh generasi muda.

Realitas sosial ini mengindikasikan bahwa paparan internet terhadap generasi muda telah memungkinkan mereka mengenal kriminalitas di usia dini. Penyebab utamanya adalah rendahnya pengetahuan mereka tentang literasi digital sehingga berdampak pada penggunaan media sosial secara tidak bertanggung jawab, ketidakpahaman komunikasi dunia maya sebagai bentuk komunikasi ruang publik, dan rendahnya pemikiran kritis sulit untuk membedakan berita yang dapat dipercaya dari berita bohong. Fakta yang terjadi di masyarakat Indonesia semacam ini merupakan tantangan besar yang harus dihadapi. Orang tua dan para pendidik, khususnya, memiliki peran penting untuk membentuk generasi muda yang literat digital, generasi yang memiliki pengetahuan, keterampilan, dan kecakapan menggunakan teknologi digital. Oleh karena itu, penguasaan literasi digital bagi kalangan generasi muda merupakan sesuatu yang sangat penting.

Menurut Nasrullah, dkk. (2017), di kehidupan modern seperti saat ini, penguasaan literasi digital bagi generasi yang termasuk ke dalam kategori digital native merupakan kebutuhan pokok untuk dapat beradaptasi dan berinteraksi baik di dunia nyata maupun di dunia maya. Keberadaan konten yang tidak diharapkan di dunia digital, seperti pornografi, paham radikalisme, ujaran kebencian, berita bohong, penipuan online, dll. telah merusak ekosistem digital dan hanya bisa ditangkal melalui pengetahuan dan kesadaran setiap individu tentang kecakapan menggunakan teknologi digital. Membangun generasi yang literat digital berarti membangun generasi yang memiliki keterampilan mengelola berbagi informasi, menyaring pesan yang diterima 
melalui informasi, dan berkomunikasi efektif di beragam media.

Dalam memasuki era revolusi industri 4.0, guru di level pendidikan dasar memiliki peran yang sangat penting dalam membentuk karakter generasi muda yang literat digital. Sekolah tidak hanya memiliki kewajiban untuk memberikan pelajaran tentang ilmu eksakta, sosial, maupun bahasa saja, namun turut memberikan pelajaran tentang etika menggunakan internet untuk mengakses informasi dengan benar (Nasution, Jati, \& Setia, 2019). Para guru dituntut untuk melek literasi digital sebelum dapat mengajarkannya kepada para peserta didik. Di satu sisi, tidak sedikit kita menemukan fenomena tentang tenaga pendidik yang masih kurang cakap dalam penguasaan teknologi digital terutama mereka yang abai serta kurang kreatif dan inovatif. Di sisi lain, generasi muda saat ini sangat cepat mengikuti perkembangan teknologi. Dengan demikian, para guru harus dapat mengimbangi gaya hidup para peserta didiknya dengan memiliki pengetahuan dan kesadaran yang sangat tinggi tentang penetrasi dan pengaruh teknologi digital terhadap perkembangan mental anak-anak dan remaja.

Berdasarkan pemikiran di atas, kegiatan Pengabdian Kepada Masyarakat (PPM) yang dilaksanakan ini berupa penyuluhan literasi digital yang ditujukan pada dua puluh guru Bimbingan Konseling (BK) yang mewakili sebelas Sekolah Menengah Pertama (SMP) di Kota Sukabumi, yaitu dari SMPN 1, SMPN 2, SMPN 4, SMPN 5, SMPN 6, SMPN 7, SMPN 13, SMPN 14, SMPN 15, SMPN 16, dan SMP Mardi Waluya 2. Para guru ini diharapkan melakukan pendekatan kepada siswa dan menjadi agen literasi digital sehingga dapat mentransfer pengetahuannya kepada peserta didik mereka. Hal ini sejalan gerakan literasi digital sekolah yang dicetuskan oleh Kementrian Pendidikan dan Kebudayaan, yang salah satu programnya adalah meningkatkan penyelenggaraan penyuluhan literasi digital untuk para guru.

\section{METODE}

\section{A. Kerangka Pemecahan Masalah}

Untuk menyebarluaskan informasi mengenai kecakapan penggunaan teknologi digital di lingkungan sekolah, kegiatan ini mengadakan penyuluhan literasi digital. Materi yang disampaikan tidak hanya dari hasil riset mengenai wacana kebencian dalam penggunaan bahasa di internet, tetapi juga menghadirkan narasumber yang giat memberikan penyuluhan tentang literasi digital ke sekolah-sekolah di beberapa wilayah di Jawa Barat. Materi penyuluhan berasal dari tim PPM yang didasari oleh hasil riset dan dari narasumber berdasarkan pengalamnnya sebagai penyuluh literasi digital.

\section{B. Realisasi Pemecahan Masalah}

Sebagai bentuk realisasi pemecahan masalah, kegiatan PPM ini mengadakan penyuluhan. Acara rangkaian penyuluhan terdiri dari kegiatan uji petik (pre-test), penyampaian materi, dan uji akhir (post test). Kegiatan uji petik dan uji akhir ditujukan untuk memeroleh gambar tentang pengetahuan yang dimiliki oleh para peserta tentang literasi digital dan mengukur sejauh mana materi yang disampaikan berdampak kepada para peserta. Kegiatan dilakukan pada tanggal 22 September 2020 dan dilakukan secara daring menggunakan media Google Meet.

\section{Khalayak Sasaran}

Kelompok sasaran kegiatan ini adalah dua puluh orang guru dari sebelas SMP di Kota Sukabumi, sepuluh SMP Negeri dan satu SMP Swasta. Kesebelas Sekolah Menengah Pertama di Kota Sukabumi itu adalah yaitu SMPN 1, SMPN 2, SMPN 4, SMPN 5, SMPN 6, SMPN 7, SMPN 13, SMPN 14, SMPN 15, SMPN 16, dan SMP Mardi Waluya 2. Guru-guru tersebut dipilih berdasarkan statusnya sebagai guru Bimbingan Konseling (BK). Guru-guru tersebut diharapkan dapat melakukan pendekatan dan sosialisasi terhadap para siswa SMP mengenai informasi literasi digital yang diperoleh dari kegiatan PPM ini. 
D. Metode yang Digunakan (Tahapan Kegiatan)

Sebagai tahapan untuk merealisasikan pemecahan masalah, tim pelaksana mengacu pada tahapan kegiatan Pengabdian pada Masyarakat yang tampak dalam tabel di bawah ini:

\begin{tabular}{llll}
\hline \multirow{2}{*}{ No } & \multicolumn{1}{c}{ Rencana Kegiatan } & \multicolumn{2}{c}{ Keterlibatan dalam Kegiatan } \\
\cline { 3 - 4 } & \multicolumn{1}{c}{ Survei dan Perizinan } & \multicolumn{1}{c}{ Tim PPM/Dosen } & \multicolumn{1}{c}{ Masyarakat } \\
\hline dim PPM melakukan survei & $\begin{array}{l}\text { Sasaran kegiatan: guru-guru } \\
\text { dan mengajukan perizinan } \\
\text { kegiatan PPM }\end{array}$ & SMP di Kota Sukabumi \\
& Penyusunan Materi PPM & $\begin{array}{l}\text { Tim PPM menyusun materi } \\
\text { uji petik dan uji akhir, dan }\end{array}$ & $\begin{array}{l}\text { Kelompok sasaran kegiatan } \\
\text { melakukan koordinasi }\end{array}$ \\
& & $\begin{array}{l}\text { materi penyuluhan, serta } \\
\text { menentukan narasumber. }\end{array}$ & intemal \\
3 & Pelaksanaan kegiatan & Tim PPM dan tim & Kelompok sasaran kegiatan. \\
& Pelatihan & pematerinarasumber. & \\
\hline
\end{tabular}

Gambar 1. Tahapan Kegiatan

\section{HASIL DAN PEMBAHASAN}

\section{Isi Hasil dan Pembahasan}

Kegiatan yang telah dilaksanan oleh tim PPM adalah memberikan penyuluhan tentang literasi digital bagi guru-guru SMP di Kota Sukabumi pada hari Selasa, 22 September 2020. Peserta penyuluhan terdiri dari 20 orang yang tersebar di sebelas Sekolah Menengah Pertama di Kota Sukabumi, yaitu SMPN 1, SMPN 2, SMPN 4, SMPN 5, SMPN 6, SMPN 7, SMPN 13, SMPN 14, SMPN 15, SMPN 16, dan SMP Mardi Waluya 2.

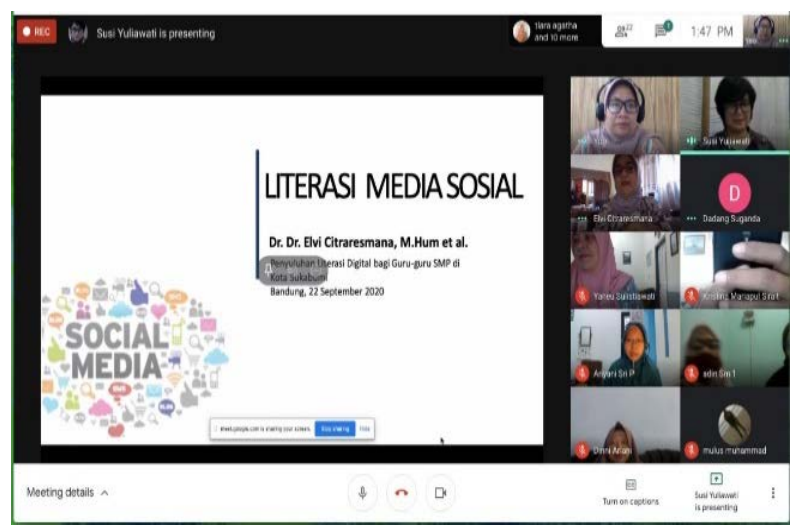

Gambar 2. Peserta menyimak penyampaian materi

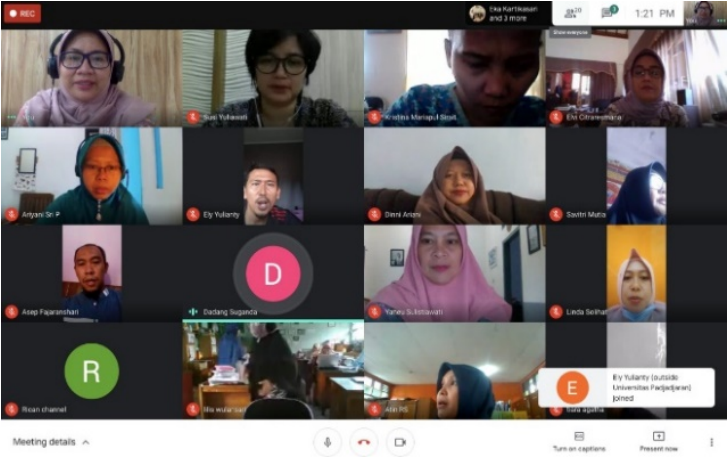

\section{Gambar 3. Peserta sedang dan mengerjakan pre-test}

Kegiatan penyuluhan diawali dengan pelaksanaan pre-test untuk memeroleh gambaran tentang pengetahuan literasi digital yang dimiliki oleh para peserta. Pre-test tersebut terdiri atas lima buah pertanyaan. Kegiatan kemudian dilanjutkan dengan pemaparan materi yang diberikan oleh Prof. Dr. Dadang Suganda, M.Hum. sebagai ketua tim pelaksana kegiatan PPM dan Dr. Elvi Citraresmana, M.Hum sebagai pemateri luar. Materi yang diberikan dalam penyuluhan tersebut mencakup informasi penting terkait literasi digital seperti:

1. Dampak positif dan negatif teknologi digital.

2. Prinsip-prinsip dasar literasi digital dan media sosial.

3. Undang-Undang ITE.

4. Konten negatif dalam internet: hoax dan ujaran kebencian.

5. Strategi mengenali berita terpercaya dan berita bohong.

Materi lainnya yang disampaikan adalah pengertian terkait istilah literasi digital. Istilah literasi digital bukanlah istilah baru. Istilah itu telah diperkenalkan oleh Gilster pada tahun 1997 melalui bukunya yang berjudul "Digital Literacy”. Menurutnya, literasi digital adalah kompetensi untuk memahami dan menggunakan informasi dari berbagai sumber digital. Gilster (1997) juga menegaskan bahwa kompetensi itu tidak hanya meliputi keterampilan membaca, tetapi juga keterampilan berpikir secara kritis untuk mengevaluasi berbagai informasi yang 
diperoleh melalui media digital. Sejalan dengan ini, Bawden (2001) menambahkan bahwa literasi digital lebih banyak dihubungkan

Seorang individu yang literat digital mengembangkan keterampilan untuk mencari informasi digital dan membangun strategi untuk mengeksplorasi mesin pencari agar memperoleh informasi yang diperlukan secara efektif dan akurat. Gilster (1997) menjelaskan bahwa seorang literat digital harus memilki kompetensi di empat kategori, yaitu:

1. Pencarian informasi di internet, yaitu kemampuan melakukan pencarian informasi di internet dengan menggunakan mesin pencari.

2. Hypertextual navigation, yaitu kemampuan untuk membaca dan memahami hypertext, contohnya memahami cara kerja situs, mengenal istilah-istilah seperti bandwidth, http, html, dan url.

3. Evaluasi konten, yaitu kompetensi untuk berpikir kritis dan memberikan penilaian terhadap segala informasi yang diperoleh dari internet sehingga dapat mengidentifikasi keabsahan dan kelengkapan informasi yang direferensikan oleh link hypertext.

4. Pengumpulan informasi, yaitu kecakapan membangun pengetahuan dari kumpulan informasi yang diperoleh dari berbagai sumber dengan cara meraup dan mengevaluasi fakta dan opini dengan baik.

Sejalan dengan ini, Bawden (2001) menjelaskan bahwa literasi digital lebih banyak dihubungkan dengan keterampilan teknis mengakses, merangkai, memahami, dan menyebarluaskan informasi. Lebih jauh lagi, Belshaw (2011) menjelaskan bahwa ada delapan unsur penting untuk mengembangkan literasi digital, yaitu:

1. Kultural, yaitu pemahaman tentang ragam konteks pengguna dunia digital;

2. Kognitif, yaitu daya pikir dalam menilai konten;

3. Konstruktif, yaitu reka cipta sesuatu yang ahli dan aktual; dengan keterampilan teknis mengakses, merangkai, memahami, dan menyebarluaskan informasi.

4. Komunikatif, yaitu memahami kinerja jejaring dan komunikasi di dunia digital;

5. Kepercayaan diri yang bertanggung jawab;

6. Kreatif, yaitu melakukan hal baru dengan cara baru;

7. Kritis dalam menyikapi konten; dan

8. Bertanggung jawab secara sosial.

Dari keseluruhan unsur di atas, aspek kultural merupakan unsur terpenting karena pemahaman tentang konteks pengguna akan membantu aspek kognitif dalam menilai konten.

Berdasarkan beberapa definisi literasi digital yang dipaparkan di atas, dapat disimpulkan bahwa literasi digital adalah pengetahuan dan kecakapan untuk memanfaatkan media digital, perangkat komunikasi, dan jaringan. Pengetahuan tersebut dapat membentuk individu yang cakap dalam menemukan, mengevaluasi, menggunakan, membuat, dan memanfaatkan informasi secara sehat, bijak, cerdas, cermat, tepat, dan patuh hokum. Sebagai hasilnya, individu tersebut mampu berkomunikasi dan berinteraksi di kehidupan sehari-hari dengan baik.

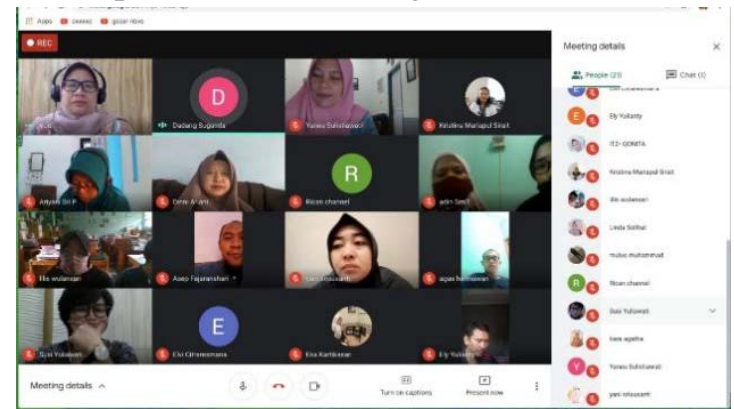

Gambar 4. Peserta sedang menyimak materi 


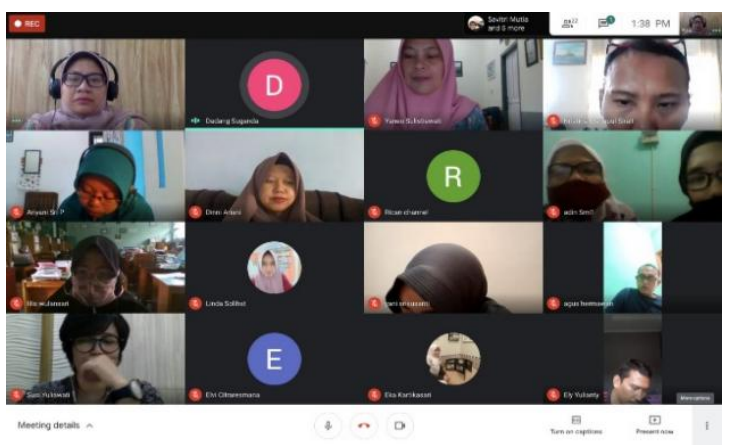

Gambar 5. Peserta sedang mengerjakan postest

Dalam kegiatan penyuluhan yang dilakukan, kegiatan bukan hanya dalam bentuk ceramah satu arah, tetapi para peserta diberi juga kegiatan praktik. Kegiatan praktik dilakukan dengan memberikan contoh-contoh penggunaan bahasa atau penyebaran informasi yang diperoleh dari internet dan mereka diminta untuk memberikan tanggapan evaluasi terhadap penggunaan bahasa dan informasi yang tersebar tersebut. Kemudian, kegiatan diakhiri dengan pelaksanaan post-test untuk melihat sejauh mana mereka dapat menyerap informasi dari penyuluhan ini.

Dari hasil pre-test, nilai rata-rata yang diperoleh oleh peserta adalah 32,94 dengan rentang nilai 10-50. Sementara itu, dari hasil post-test, nilai rata-rata nya adalah 43,33 dengan rentang nilai 30-50. Berdasarkan hasil pre-test dan post-test, peningkatan pengetahunan para guru tercermin dari kemampuannya memahami istilah-istilah yang berkaitan dengan literasi digital seperti pengertian literasi digital, hoax, hate speech, dan digital native; cara-cara untuk mendeteksi berita akurat dan hoax; dampak negatif ujaran kebencian dan berita bohong bagi keharmonisan sosial; dan perbuatan-perbuatan yang dikategorikan sebagai pelanggaran hukum menurut UU ITE.

Kenaikan nilai rata-rata dan rentang nilai dari kedua tes tersebut menunjukkan bahwa penyuluhan yang diberikan ini telah menambah wawasan para peserta tentang literasi digital. Dari pelatihan ini diharapkan dapat menambah pengetahuan dan lebih membangun kesadaran tentang pentingnya menjadi literat digital bagi mereka yang memiliki peran penting di dunia pendidikan. Selanjutnya, para guru tersebut diharapkan dapat melakukan pendekatan dan sosialisasi tentang literasi digital terhadap para siswa didiknya sehingga mereka dapat memberikan kontribusi nyata dalam membentuk generasi muda Indonesia yang bijak menggunaan teknologi dan memiliki kesadaran tinggi untuk menjaga keutuhan bangsa.

\section{SIMPULAN}

Literasi digital adalah istilah yang mengacu pada pengetahuan dan kecakapan menggunakan media digital, perangkat komonikasi, dan jaringan untuk menemukan, membuat, dan mengevaluasi informasi, serta menggunakannya secara bijak, cerdas, cermat, tepat, sehat, dan taat hukum dalam rangka menjalin interaksi dalam kehidupan sehari-hari. Kegiatan PPM ini ditujukan untuk membantu meningkatkan pengetahuan dan kesadaran para pendidik di tingkat Sekolah Menengah Pertama tentang dampak penggunaan teknologi digital sehingga mereka dapat memanfaatkan teknologi digital secara bijak dan penuh bertanggung jawab. Selanjutnya, pengetahuan dan kesadaran tersebut dapat mereka tularkan pada para anak didik mereka. Dari kegiatan penyuluhan ini, perubahan yang tampak dari adalah peningkatan pengetahuan para peserta mengenai cara berkomunikasi yang bijak di media sosial, perbedaan berita akurat dan hoax, dan bahaya ujaran kebencian bagi keharmonisan sosial.

\section{UCAPAN TERIMAKASIH}

Terima kasih kepada pihak Universitas Padjadjaran yang telah memberikan dukungan dana bagi pelaksanaan Pengabdian pada Masyarakat tahun 2020 ini melalui skema PPM yang terintegrasi dengan ALG Unpad. 


\section{DAFTAR PUSTAKA}

Bawden, D. (2001). Information and Digital Literacies: A Review of Concepts. Journal of Documentation, 57(2), 218. Diakses pada 24 September 2020

dari https://www.learntechlib.org/p/9431 $7 /$.

Belshaw, D. (2012). What is Digital Literacy?. A Pragmatic investigation (Doctoral dissertation, Durham University). Diakses pada September 23, 2020 dari http://etheses.dur.ac.uk/3446/1/Ed.

Gilster. (1997). Digital Literacy. New York: Wiley

Kemp, S. (2020). Digital 2020: Indonesia. Diakes pada 20 September 2020 dari https://datareportal.com/reports/digi tal-2020-indonesia

Luxiana, K.M (2020). Puluhan Orang Korban Penipuan Online Sindikat Bocah SMP Rugi Rp 100 Juta. Diakses pada 20 September 2020 dari https://news.detik.com/berita/d5178941/puluhan-orang-korbanpenipuan-online-sindikat-bocah-smprugi-rp-100-juta

Nasrullah, R. dkk. (2017). Materi Pendukung Literasi Digital. Kementerian Pendidikan dan Kebudayaan.

Nasution, Z., Jati, A. K. N., \& Setia, S. (2019). PELATIHAN ETIKA BERBAHASA

BAGI SISWA UNTUK

MENINGKATKAN KETERAMPILAN

BERKOMUNIKASI DI MEDIA

SOSIAL. Kumawula: Jurnal Pengabdian Kepada Masyarakat, 2(2).

Nursalikah, A. (2016). 25 Ribu Anak Indonesia Akses Pornografi Setiap Hari. Diakses pada $20 \quad$ September 2020 dari https://nasional.republika.co.id/berit a/nasional/umum/16/04/24/o64tss36625-ribu-anak-indonesia-aksespornografi-setiap-hari

Rizkinaswara, L. (2019). Pengguna Internet di Indonesia. Diakses pada 20 September 2020 dari https://aptika.kominfo.go.id/2019/0

8/penggunaan-internet-di-indonesia/ 